\title{
Relationship of soil physical quality parameters and maize yield in a Brazilian Oxisol
}

\author{
Anderson C. Bergamin ${ }^{1 *}$, Antonio C.T. Vitorino², Fábio R. Souza ${ }^{1}$, Luciano R. Venturoso ${ }^{3}$, \\ Luara P.P. Bergamin ${ }^{4}$, and Milton C.C. Campos $^{5}$
}

In Brazilian agriculture, maize (Zea mays L.) is prominent because of its magnitude of grain production. However, soil compaction changes negatively the soil physical attributes, limiting the crop growth. This study aimed to evaluate physical attributes of a clayey Oxisol (Rhodic Hapludox) under no-tillage, and the relationships between these attributes with maize yield in the Midwest region of Brazil. Besides this, indicators of soil physical quality when subjected to levels of compaction were determined. A randomized complete block design was applied with five replicates. Treatments were induced levels of compaction: a reference condition that reflects $8 \mathrm{yr}$ of no-tillage (NT); no-tillage with additional compaction by tractor traffic in one (NT-1), two (NT-2), four (NT-4), and six passes (NT-6). There was significant correlation $(P<0.01)$ between all physical attributes of the studied soil. Maize yield was positively correlated to macroporosity $(\mathrm{r}=0.41 *)$, and negatively to penetration resistance $(\mathrm{r}=-0.42 *)$, geometric mean diameter $\left(\mathrm{r}=-0.51^{*}\right)$, and mean weighted diameter $(\mathrm{r}=-0.53 *)$. The index of emergence speed, stem diameter, plant height, grain mass, and grain yield decreased as soil compaction increased. The physical attributes evaluated, especially the resistance to penetration and soil macroporosity, reveal the level of soil compaction and can be used as soil physical quality indicators.

Key words: Correlation, no-tillage, physical attributes, tractor traffic, Zea mays.

\section{INTRODUCTION}

Maize (Zea mays L.) is one of the most important crops in Brazilian economy, with 73 million tons produced in the 2011-2012 growing season (CONAB, 2013). This crop is typically cultivated in two planting seasons: In summer (or the first season), and the fall/winter (second season). In Mato Grosso do Sul (MS) state, the average maize yield in 2011-2012 was $6.7 \mathrm{t} \mathrm{ha}^{-1}$, producing 6.6 million tons (CONAB, 2013).

To keep soil physical quality is vital for the success of crop growth, maximizing yield and achieving sustainability. However, soil has its physical attributes

${ }^{1}$ Universidade Federal de Rondônia (UNIR), Departmento de Agronomia, Av. Norte/Sul 7300, Rolim de Moura, RO, Brasil. "Corresponding author (anderson.bergamin@unir.br).

${ }^{2}$ Universidade Federal da Grande Dourados (UFGD), Faculdade de Ciências Agrárias, Rodovia Dourados-Itahum, km 12, Cidade Universitaria, Dourados, MS, Brasil.

${ }^{3}$ Instituto Federal de Rondônia (IFRO), Rodovia RO 257, km 13, Sentido Machadinho do Oeste, Zona Rural Ariquemes, RO, Brasil. ${ }^{4}$ Centro Universitário da Grande Dourados (UNIGRAN), Faculdade de Ciências Exatas e da Terra, Avenida Manaus 4283, Centro, Rolim de Moura, RO, Brasil.

${ }^{5}$ Universidade Federal do Amazonas (UFAM), Instituto de Educação, Agricultura e Meio Ambiente, Rua de agosto 786, Humaitá, AM, Brasil.

Received: 21 October 2014.

Accepted: 26 April 2015.

doi: $10.4067 /$ S0718-58392015000400013 significantly changed by excessive traffic; this is due to the applied tensions exceeding the load support capacity, affecting negatively soil structure and crop yields (Pagliai and Jones, 2002).

In areas with inadequately managed no-tillage systems, one of the main causes for soil degradation is compaction. Soil compaction is one of the major problems of modern agriculture and it occurs in a wide range of soils and climates (Agostini et al., 2012). In no-tillage systems, it is usually caused by the soil superficial compaction due to machinery traffic. Depending on the level it occurs, also they induce changes of the pore functions and of pore continuity because of plastic soil deformation, consequently, not only water infiltration will be reduced but it also causes reduced gas, and water fluxes but greater heat fluxes, as well as water logging, interflow, runoff and soil erosion (Horn and Fleige, 2009), not allowing plants to develop properly (Silveira Junior et al., 2012). These processes not only result in a reduction of the productivity of the site, but are also responsible for water pollution by surface runoff and higher energy requirements to obtain a comparable yield (Horn, 2003).

There is no total agreement about which compaction level effectively reduces crop yields. It is well known that bulk density (Bd), resistance to penetration (RP), macroporosity (Macro), and total porosity (Tp) soil characterize the compaction status (Suzuki et al., 2007). Bulk density has a vital role in the agronomic studies since it is strictly related to other physical attributes. For 
instance, as Bd increases, microporosity (Micro) and RP increase.

Before analyses of the application of various types of parameters (physical attributes), a first definition shall be given in order to evaluate their applicability within soil physical quality. A capacity parameter defines a general status, i.e. the composition of a given volume but not their internal structure and function while an intensity parameter includes dynamic aspects over time and space and thus it also covers the quantification of the functionality and the reaction or processes of systems within the given environmental conditions. Classical capacity parameters are therefore, e.g. the bulk density, the pore size distribution including the air capacity, plant available water capacity, or grain size distribution, texture and aggregate size classes. Intensity parameters are, e.g. hydraulic conductivity, mechanical soil strength, air permeability, aggregate or soil strength, as well as the pore continuity within the complete profile (Horn and Kutilek, 2009).

Different parameters are used in soil science to detect compaction (Suzuki et al., 2007). Normally, it can be stated that each compaction leads to a change of pore functions in soils. To detect "harmful changes of the soil", Horn and Fleige (2009) report that analyzes should be restricted to parameters which may have an effect on crop production. These authors distinguish two levels of indication for soil physical quality (low indication, defines a low significance or sensitivity, while high indication means a strong force of expression). Parameters with low indication are, e.g. the penetration resistance, effective bulk density and shear resistance, while parameters with high indication are the air capacity, saturated hydraulic conductivity, and infiltration rate (Horn and Fleige, 2009).

These attributes have been usually taken as indicators of soil quality for distinct management systems to be compared (Marchão et al., 2007). In this sense, soil quality is defined as the ability of a specific kind of soil to function, within natural or managed ecosystem boundaries, to sustain plant and animal productivity, maintain or enhance water and air quality, and support human health and habitation (Karlen et al., 1997). Consequently, our interest was to evaluate soil physical quality and its relation to maize yield in a no-tillage system under distinct compaction states caused by traffic of agricultural machinery. So, this study aimed to evaluate the relations between soil physical attributes and maize yield, in a clayey Oxisol (Rhodic Hapludox) cultivated under no-tillage system. Besides, it aimed to determine indicators of soil physical quality subjected to distinct states of inducted compaction.

\section{MATERIALS AND METHODS}

The study was performed in the Agrarian Science Experimental Farm of the Federal University of Grande Dourados (UFGD), in the municipality of Dourados (22 ${ }^{\circ} 14^{\prime} 08^{\prime}$ ' S, 5459'13” W; 434 m a.s.1.), Mato Grosso do Sul (MS), Brazil, in the season 2007-2008. The site climate classification is Cwa, according to Köppen (Köppen and Geiger, 1928). The rainfall and average air temperature observed during the maize (Zea mays L.) growth are shown in Figure 1. The studied soil was classified as clayey Rhodic Hapludox (Oxisol) according to the Soil Taxonomy (USDA, 1999) and dystroferric Red Latosol with high-clay texture by the Brazilian Soil Taxonomy System (Embrapa, 2013), whose texture determined by the pipette method was $644 \mathrm{~g}$ clay $\mathrm{kg}^{-1}, 203 \mathrm{~g}$ silt kg-1 and $153 \mathrm{~g}^{-1}$ sand $\mathrm{kg}^{-1}$, in the $20-\mathrm{cm}$ superficial layer the surface horizon (Ap). The chemical features were: $\mathrm{pH}$ in water 5.7, $0.51 \mathrm{cmol}_{\mathrm{c}} \mathrm{K} \mathrm{kg}^{-1}, 6.92$ $\mathrm{cmol}_{\mathrm{c}} \mathrm{Ca}^{2+} \mathrm{kg}^{-1}, 3.10 \mathrm{cmol}_{\mathrm{c}} \mathrm{Mg}^{2+} \mathrm{kg}^{-1}, 0.0 \mathrm{cmol}_{\mathrm{c}} \mathrm{Al}^{3+} \mathrm{kg}^{-1}$, $\mathrm{H}+\mathrm{Al}=5.80 \mathrm{cmol}_{\mathrm{c}} \mathrm{kg}^{-1}, 7.0 \mathrm{mg} \mathrm{P} \mathrm{kg}^{-1}$, and $3.7 \%$ organic matter (Embrapa, 1997).

The experimental design used was the randomized block, with five treatments and five replicates. Treatments were applied in an area under no-tillage system for 8 yr, with crop rotation, being soybean (Glycine max [L.] Merr.) and maize in the summer and black oat (Avena strigosa Schreb.) and maize (as $2^{\text {nd }}$ season) in the fallwinter. Soil additional compaction was provided by the tractor passing one (NT-1), two (NT-2), four (NT-4), and

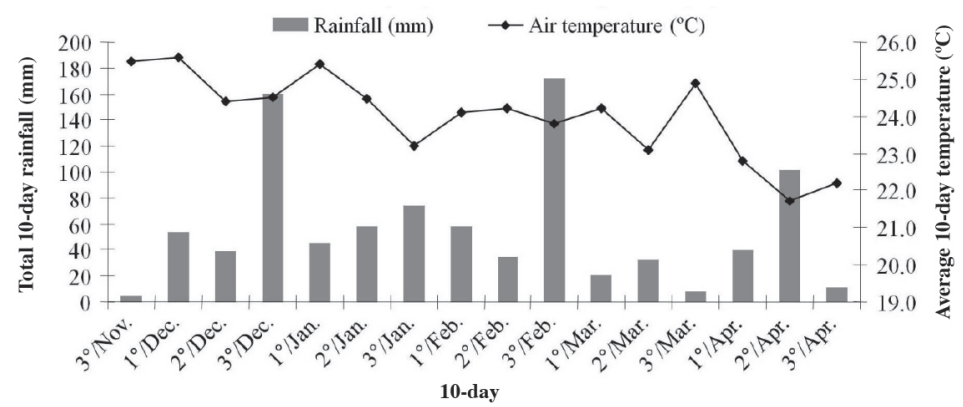

3\%/Nov.: Period from 21 to 30 November, $1^{\circ} /$ Dec.: period from 1 to 10 December, $2^{\circ} /$ Dec.: period from 11 to 20 December, and so on in the remaining dates.

Figure 1. Total rainfall and average air temperature observed each 10 days in the experimental area, from November 2007 to April 2008. 
six (NT-6) times on the crop area. Control treatment (NT) consisted in the absence of additional traffic. The plot area was $18 \mathrm{~m}^{2}$ (5-m long and 3.6-m wide). Each experimental unit was composed by four $4-\mathrm{m}$ long rows of maize. The treatments with additional compaction were applied in 13 November 2007, when soil water content was $0.28 \mathrm{~kg} \mathrm{~kg}^{-1}$ in the 20-cm deep superficial layer, determined according to Embrapa (1997). A tractor with a $77.3 \mathrm{~kW}$ engine and mass of $5 \mathrm{t}$ equipped with pneumatic tires inflated at $96 \mathrm{kPa}$ in front tires (14.9-24 R1) and at $110 \mathrm{kPa}$ in the rear tires (18.4-34 R1). The mass distribution was 39\% in the front axis and $61 \%$ in the rear axis. Compaction was performed by the pass tractor wheel in the whole plot surface. The whole plot was compacted in a series of passes, each beside the previous pass, so that the whole area was covered to assure homogeneous compaction. The number the tractor passed on the plot surface varied according to the treatment, and traffic was superimposed on the previous one. In all treatments, the tractor forward speed was $1.67 \mathrm{~m} \mathrm{~s}^{-1}$.

Maize sowing ('BRS 3150') was performed in 22 November 2007, by a no-till 4-row crop planter (plus fertilizer) with $90 \mathrm{~cm}$ between rows. The coulter originally used as furrow device for seeds was replaced by discs for seed deposition, to avoid elimination of any possible compaction effect. The amount of seed applied was enough to obtain a population of 56000 plants ha $^{-1}$. Base fertilization applied was $40 \mathrm{~kg}$ mineral N, $53 \mathrm{~kg} \mathrm{P}$, and 33 $\mathrm{kg} \mathrm{K}$ per hectare. For coverage fertilizer it was applied $100 \mathrm{~kg} \mathrm{~N} \mathrm{ha}^{-1}$ in the form of ammonium sulfate and 33 $\mathrm{kg} \mathrm{K} \mathrm{ha}{ }^{-1}$ in the form of potassium chloride, $30 \mathrm{~d}$ after seedling emergence. The index of emergence velocity (IEV) is an analysis of seed vigor, where seeds will be more vigorous how much faster the plantlet emergence in the field occurs. The IEV was evaluated according to Maguire (1962), as follows:

$$
I V E=(E 1 / N 1)+(E 2 / N 2)+\ldots+(E n / N n)
$$

where $E 1$ is number of plantlets that emerged in the field; $N 1$ is number of days from seeding to the first count; $E 2$ is number of plantlets in the second count; $N 2$ is number of days from seeding to the second count; $n$ is last count.

Plant height and stem diameter were determined when maize plants were in the phenological stage R6 (physiological maturity), in 10 plants per plot randomly selected. Plant height was determined from soil surface to the insertion of the last expanded leaf, while stem diameter was determined as the average of two measurements made in the third internode.

The useful area considered in the plot was $3 \mathrm{~m}$ of the two central rows in each experimental plot. Maize yield was determined extrapolating grains produced in the useful area to 1 ha, assuming 14\% water content in grains. The evaluated components of maize yield were: Number of grain rows per cob, number of grains per row, and cob length, in 10 cobs per plot. It was also determined the mass of 100 grains, weighing them after manual counting of five samples of 100 grains each per plot. There was correction for $14 \%$ water content for the grain mass determination.

Soil samples with preserved structure were collected for the determination of bulk density $(\mathrm{Bd})$, soil resistance to penetration (RP), and porosity. Steel cylinders (diameter $5.57 \mathrm{~cm}$, height $4.1 \mathrm{~cm}$ ) were used to collect samples in the depths 0-5, 5-10, 10-15, and 15-20 cm. Samples were collected between maize rows. Three sub-samples were collected in each plot and depth, for the average data to be determined and for it to represent the plot. Samples were saturated by means of gradual elevation of a water layer until to reach two thirds of the cylinder height. Once saturated, samples were placed on the tension table, and applied up a tension $6 \mathrm{kPa}$. On equilibrium in this tension, samples were weighed to measure the mass of water after draining. The water content in this tension was considered as the microporosity (Micro) according to Embrapa (1997). These samples were saturated again and subjected to tension of $10 \mathrm{kPa}$, in Richards' chamber according to Klute (1986).

When samples got the equilibrium at this tension (10 $\mathrm{kPa}$ ), RP was measured using an electronic penetrograph (Milson Evaldo Serafim, Universidade Federal da Grande Dourados, Dourados, Mato Grosso do Sul, Brazil) with constant speed of penetration of $1 \mathrm{~cm} \mathrm{~min}^{-1}$, with diameter of $4 \mathrm{~mm}$ in the stick base and semiangle of $30^{\circ}$, developed by Serafim et al. (2008). The values obtained in the most superior and inferior layers were not considered aiming to eliminate the peripheral effect of the sample (Bradford, 1986). The data collection frequency for RP was $0.25 \mathrm{~s}$, which obtained 800 measurements per sample to compose the average. After this, samples were taken to the muffle furnace at $105-110^{\circ} \mathrm{C}$ for $48 \mathrm{~h}$, for the volumetric water content and $\mathrm{Bd}$ to be determined by the volumetric ring method. The total soil porosity (TP) was determined in the undisturbed samples from the saturation soil water content, with all pores water filled; and macroporosity (Macro) was calculated by the difference between TP and Micro (Embrapa, 1997).

The distribution of aggregates was determined for the four soil depths by wet sieving. Soil blocks were collected with air-dried preserved structure and sieved in meshes of 9.52 and $4.76 \mathrm{~mm}$. The aggregates taken from the 4.76$\mathrm{mm}$ mesh were used to analyze the wet aggregate stability, which was performed passing the sample through a set of meshes of 2.0, 1.0, 0.5, and $0.105 \mathrm{~mm}$, subjected to vertical oscillations by $15 \mathrm{~min}$ in a frequency of 0.533 Hz. The geometric mean diameter (GMD) and the mean weighted diameter (MWD) were adopted as stability indices, determined as suggested by Kemper and Rosenau (1986). The soil physical quality was evaluated using graphical models, in which each attribute was placed in an axis (Costa et al., 2006). The graphics evaluate qualitatively the tendency of the impact in the compaction status over no-tillage system. The soil physical attributes 
measured in the no-tillage system without additional compaction (NT) were adopted as reference. To express the effect of treatments for each attribute used (Macro, $\mathrm{RP}, \mathrm{Bd}$, and Tp) the numeric indicator (IN) was defined as Equation [1], according to Marchão et al. (2007). Values of the IN will be positive in observed value higher than the reference and negative if it is lower than the reference:

$$
I N=\left[\left(\text { Macro }_{O B S}-\text { Macro }_{N T}\right) / \text { Macro }_{N T}\right] \times 100
$$
where $I N$ is numeric indicator $(\%) ;$ Macro $_{O B S}$ is the macroporosity observed in the treatments; and Macro $_{N T}$ is the macroporosity of treatment NT which is the reference.

The data from maize were subjected to ANOVA and, when it was significant, Duncan's test $(P<0.05)$ was applied to compare averages. A correlation matrix (Pearson correlation) was done aiming to perform simple linear correlations to two-by-two combinations of the physical attributes studied with maize yield. To do so, the software SAEG (Sistema para Análises Estatísticas, Universidade Federal de Viçosa, Viçosa, Brazil) was used (Ribeiro Júnior, 2001).

\section{RESULTS AND DISCUSSION}

There was correlation $(P<0.01)$ among all soil physical attributes evaluated (Table 1), since the increase on the compaction status reflected in the increase of $\mathrm{Bd}$, resulting in more RP and alteration in the soil porosity. To Agostini et al. (2012), soil pore dynamics may be reflected in Bd and RP variations. Freddi et al. (2008) studied a clayey eutroferric Oxisol and observed high correlation coefficients among Macro, Micro, Tp, and $\mathrm{Bd}$. The increase of $\mathrm{Bd}$ diminished Macro and $\mathrm{Tp}$, corroborating with Horn (2003) and Silveira Junior et al. (2012). On the other hand, Micro, volumetric water content and RP, geometric mean diameter (GMD) and mean weighted diameter (MWD) (Table 1) increased. This is similar to the findings of Silveira Junior et al. (2012) that studied porosity and RP in function to the $\mathrm{Bd}$. The results obtained can be due to compaction, which modifies the soil structure and increases micropores compared to macropores. To Martínez et al. (2008) the greater Bd, RP, and Micro under no-tillage are indicators of soil compaction and

Table 1. Pearson correlation among physical attributes in the layer 0-20 cm in a clayey Oxisol (Rhodic Hapludox).

\begin{tabular}{|c|c|c|c|c|c|c|c|c|}
\hline & Macro & Micro & $\mathrm{Tp}$ & $\mathrm{RP}$ & $\mathrm{W}_{\theta}$ & $\mathrm{Bd}$ & GMD & MWD \\
\hline Macro & 1 & & & & & & & \\
\hline Micro & $-0.78 * *$ & 1 & & & & & & \\
\hline $\mathrm{Tp}$ & $0.84 * *$ & $-0.32 * *$ & 1 & & & & & \\
\hline $\mathrm{RP}$ & $-0.81 * *$ & $0.44 * *$ & $-0.84 * *$ & 1 & & & & \\
\hline $\mathrm{W}_{\theta}$ & $-0.81 * *$ & $0.88 * *$ & $-0.46 * *$ & $0.54 * *$ & 1 & & & \\
\hline $\mathrm{Bd}$ & $-0.82 * *$ & $0.70 * *$ & $-0.63 * *$ & $0.71 * *$ & $0.76^{* *}$ & 1 & & \\
\hline GMD & $-0.85 * *$ & $0.60 * *$ & $-0.77 * *$ & $0.77 * *$ & $0.70 * *$ & $0.70 * *$ & 1 & \\
\hline MWD & $-0.62 * *$ & $0.40 * *$ & $-0.59 * *$ & $0.65 * *$ & $0.45^{* *}$ & $0.50 * *$ & $0.78^{*} *$ & 1 \\
\hline \multicolumn{9}{|c|}{$* * P \leq 0.01$} \\
\hline $\begin{array}{l}\text { Macro: } \\
\text { resistan } \\
\text { bulk de } \\
\text { diamete }\end{array}$ & ensity; GI & MD: geo & $\begin{array}{l}\text { Micro: } \\
(-0.01 \mathrm{M} \\
\text { metric }\end{array}$ & $\begin{array}{l}\text { hicroporo } \\
(\mathrm{Pa}) \cdot \mathrm{W}\end{array}$ & $\begin{array}{l}\text { sity; Tp } \\
\text { volumetr } \\
\text { neter; an }\end{array}$ & $\begin{array}{l}\text { total p } \\
\text { ic water } \\
\text { MWD }\end{array}$ & $\begin{array}{l}\text { orosity; } \\
(-0.01 \mathrm{M} \\
\text { : mean }\end{array}$ & $\begin{array}{l}\text { RP: soil } \\
\text { Pa); Bd: } \\
\text { veighted }\end{array}$ \\
\hline
\end{tabular}

thereby loss of soil macropores. Thus, because the various processes also occur during land management, a further and normally more pronounced alteration of the following will occur, being the pore diameter reduced due to soil compaction because of soil weakening even at higher bulk density and possibly a delayed or reduced plant growth, which may result in lower yield (Horn, 2003).

In a clayey Oxisol, after 16 yr of no-till system, with the following crop rotation: maize and soybean in the spring/summer period; and wheat (Triticum aestivum L.) and oat with vetch (Vicia sativa L.) consortium in the fall/winter, Silveira Junior et al. (2012) evaluating the effects these cover crops and chiseling on physical properties verified that with $\mathrm{Bd}$ increases, reducing Macro and, consequently, increasing Micro and reducing Tp. The greater Bd under no-tillage is probably a direct consequence of the compaction related with management in the no-tillage system (Reynolds et al., 2002). In notillage, Reynolds et al. (2002) obtained critical densities of 1.52 and $1.56 \mathrm{~g} \mathrm{~cm}^{-3}$, for Brookston clay loam and Guelph loam, respectively.

Horn and Fleige (2009) verified positive linear correlations between "precompression stress" (Pc) and Macro (> $50 \mathrm{~mm}=$ air capacity). This field experiment was conducted to measure the stress distribution at 20,40, and $60 \mathrm{~cm}$ depth of a Stagnic Luvisol in Northern Germany, using a tractor-pulled mono-wheeler with a S-H 650/75 tire mounted, applying to the soil two different loads (3.3 and $6.5 \mathrm{Mg}$ ). These authors found a significant Macro reduction when applied at a defined stress of $90 \mathrm{kPa}$ at field capacity on air capacity in comparison to the initial state in the subsoil. A low or high value of the Pc does not emphasize positive or negative reactions on soil functions due to loading. In fact, soils with greater Pc and "positive" soil functions are the ideal case (Horn and Fleige, 2009).

Geometric mean diameter was positively and linearly correlated to MWD. Increasing aggregate diameter reduced Tp and Macro, and increased Micro and Bd (Table 1). The increased contribution of finer pores (Micro), combined with the increased number of contact points between soil particles, leads to greater internal aggregate strength (Ferrero et al., 2007). Soil compaction may have caused the increase aggregate stability due to mechanical aggregation that occurs as a result of pressure exerted by the compression (Blanco-Canqui et al., 2005), leading to the union of particles with high moisture in the soil. Silva et al. (2006) found that this process was detected in clayey Oxisol. With respect to describing the effects of compaction on mechanical properties of structured soil, different studies carried out on soil compaction showed that up to a certain level of compaction, depending of the amplitude of the strength, aggregates remain rigid and only the inter-aggregate structure is affected by the compaction (Alaoui et al., 2011). In aggregated soils (clayey soil), the loss of porosity on compaction is attributed to the collapse of inter-aggregate pores (Angers et al., 1987). 
Li and Zhang (2009) reported that the volume of the compressible inter-aggregate pores is closely related to the final void ratio of the compacted soil and that changes to inter-aggregate pores are dominant during compaction, but changes to intra-aggregate pores are dominant during saturation and drying. Pore geometry is influenced by mechanical compaction and wetting because of soil settlement, and filling of intra-aggregate pore space, as a result, porosity and median pore-size will decrease (Leij et al., 2002). Thus, soil structure formation due to shrinkage and swelling results not only in the well-known heterogenization of the pore size distribution in the bulk soil by the formation of coarse inter-aggregate and finer and fewer intra-aggregate pores, but also in variations in the physical properties of single aggregates (Horn, 1990). The increase of RP caused reduction in Macro and Tp, and increased Micro, volumetric water content, GMD, and MWD (Table 1). These results agree with Silva et al. (2006), who evaluated physical attributes of two Oxisols, verified positive linear correlation $(P<0.001)$ between RP and Micro and negative for RP with Tp and Macro. The RP increases with soil depth and years under management in no-tillage system (Martínez et al., 2008). The increased RP with soil depth and time of treatment is most probably related to planter weight (Botta et al., 2005) and to the relatively high soil water content at planting. Martínez et al. (2008) working in a sandy clay alluvial soil (coarse loamy over sandy, skeletal, mixed, thermic Entic Haploxeroll) observed higher RP under no-tillage as compared to conventional tillage in the first $15 \mathrm{~cm}$ depth.

The stability of aggregates measured by aggregate diameter percentage larger and smaller than $2 \mathrm{~mm}$, at 0-5 and $5-10 \mathrm{~cm}$, was changed by applied treatments (Table 2 ), whereas in the $10-20 \mathrm{~cm}$ layer no differences were observed between treatments. There was an increase in aggregate percentage larger than $2 \mathrm{~mm}$ with increasing number of tractor traffic. At $0-10 \mathrm{~cm}$, mean DMG and DMP values found in this study were 2.71 and $2.81 \mathrm{~mm}$, respectively.

No-tillage treatment presented the lowest aggregate percentage $>2 \mathrm{~mm}$ in the layer 0.0 to $0.10 \mathrm{~m}$ (Table 2). The increased stability of aggregates observed by increasing

Table 2. Percentage of aggregates with larger and smaller diameter than $2 \mathrm{~mm}$ at different depths and number of tractor traffic in a clayey Oxisol (Rhodic Hapludox).

\begin{tabular}{lcccccc}
\hline & \multicolumn{2}{c}{ Layer from $0-5 \mathrm{~cm}$} & & \multicolumn{2}{c}{ Layer from $5-10 \mathrm{~cm}$} \\
\cline { 2 - 3 } \cline { 6 - 7 } Treatments $^{1}$ & $>2.00 \mathrm{~mm}$ & $<2.00 \mathrm{~mm}$ & & $>2.00 \mathrm{~mm}$ & $<2.00 \mathrm{~mm}$ \\
\cline { 2 - 3 } \cline { 5 - 6 } NT & $71.08 \mathrm{c}$ & $28.92 \mathrm{a}$ & & $71.90 \mathrm{c}$ & $28.10 \mathrm{a}$ \\
NT-1 & $71.89 \mathrm{~b}$ & $28.11 \mathrm{~b}$ & & $73.25 \mathrm{~b}$ & $26.75 \mathrm{~b}$ \\
NT-2 & $72.43 \mathrm{~b}$ & $27.57 \mathrm{bc}$ & & $74.33 \mathrm{a}$ & $25.67 \mathrm{c}$ \\
NT-4 & $72.97 \mathrm{a}$ & $27.03 \mathrm{c}$ & & $74.60 \mathrm{a}$ & $25.40 \mathrm{c}$ \\
NT-6 & $73.24 \mathrm{a}$ & $26.76 \mathrm{c}$ & & $74.87 \mathrm{a}$ & $25.13 \mathrm{c}$ \\
\hline CV, \% & 0.60 & 0.59 & 0.62 & 0.60 \\
\hline
\end{tabular}

${ }^{1} \mathrm{NT}$ : no-tillage system; no-tillage with additional compaction by tractor traffic in one (NT-1), two (NT-2), four (NT-4), and six passes (NT-6).

Means followed by the same letter in the column did not differ according to the Duncan's test $(P \leq 0.05)$. the amount of aggregates $>2 \mathrm{~mm}$, with increasing number of tractor passes can likely be attributed to mechanical aggregation that occurs as a result of pressure exerted by the compaction, leading to the union of particles under high soil moisture. Silva et al. (2006) found similar results when they worked with compaction pressures up to 120 $\mathrm{kPa}$ in Oxisol clay.

Considering $0.10 \mathrm{~cm}^{3} \mathrm{~cm}^{-3}$ as critical Macro for the adequate plant growth (Suzuki et al., 2007), one observed that this value correspond to a $\mathrm{Bd} c a .1 .36 \mathrm{~g} \mathrm{~cm}^{-3}$ and to a RP ca. 0.81 MPa (Figure 2), indicating higher risk to constraint the growing and development of plants, as reported by Suzuki et al. (2007). Reynolds et al. (2002) comparing values for some soil physical quality (SPQ) parameters obtained from long-term conventional tillage cropping, long-term no-tillage cropping, and virgin woodlot treatments located on Fox sand $(90 \%$ sand, 5\% silt, 5\% clay; Psammentic Hapludalf), Guelph loam (36\% sand, $48 \%$ silt, $16 \%$ clay; Mollic Hapludalf), and Brookston clay loam (28\% sand, $35 \%$ silt, $37 \%$ clay; Typic Argiaquoll) soils observed that under no-tillage system, loam and clay loam soils were not well aerated, with both air capacity of total soil and soil matrix, with both falling near or substantially below $0.10 \mathrm{~cm}^{3} \mathrm{~cm}^{-3}$ minimum, consequently crop roots are experimenting periodic aeration deficits, especially those within the soil matrix. In addition, these deficits are likely to be particularly severe and frequent under no-tillage at the clay loam site, given that air capacity of the soil matrix was only about $0.04 \mathrm{~cm}^{3} \mathrm{~cm}^{-3}$.

Freddi et al. (2008) found in a clayey Oxisol, critical values for bulk density of $1.36 \mathrm{~g} \mathrm{~cm}^{-3}$, with the aerial porosity decreased. Servadio et al. (2005) in a Haplic Calcaric Cambisol with $168 \mathrm{~g}$ sand kg-1, $480 \mathrm{~g}^{-1}$ silt kg ${ }^{-1}$ and

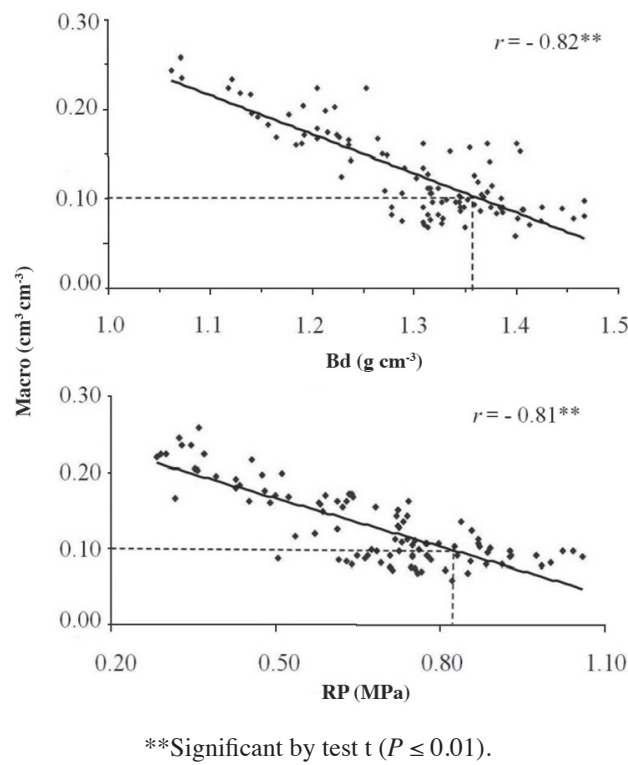

Figure 2. Macroporosity soil (Macro) according to bulk density (Bd) and soil resistance to penetration (RP). Layer from $0-20 \mathrm{~cm}(\mathrm{n}=100)$. 
$352 \mathrm{~g}$ clay $\mathrm{kg}^{-1}$, evaluating relations between $\mathrm{PR}$ and Macro, at $0-10 \mathrm{~cm}(P<0.05)$ and $10-20 \mathrm{~cm}(P<0.01)$ depth, for one and four passes of the tractor with single tires and with dual tires obtained Macro below 0.10 $\mathrm{cm}^{3} \mathrm{~cm}^{-3}$ and RP of 1.36 and $1.21 \mathrm{MPa}$, in the layers from depths 0-10 and 10-20 cm, respectively. The experiment of Servadio et al. (2005) was carried out under field tests using the tractor four wheel drive (113 kW engine power) fitted with two different tire arrangements: single and dual, being tests conducted on arable soil previously ploughed and harrowed in order to check the compacting effects resulting from one to four passes of the tractor in the same track with forward speed of the tractor of 1.11 $\mathrm{m} \mathrm{s}^{-1}$ for both types of equipment.

Soil physical quality is represented in Figure 3 by a comparative graphical model for $\mathrm{RP}, \mathrm{Bd}$, Macro, and $\mathrm{Tp}$ with the relative changes for each attribute related to the no-till system without additional compaction (NT). Treatments NT-4 and NT-6 caused the biggest changes on the physical attributes evaluated. Both presented very similar results. There was a tendency to reduce these changes in deeper soil layers, with the biggest effects on depth $0-10 \mathrm{~cm}$ (Figures $3 \mathrm{a}$ and $3 \mathrm{~b}$ ). This is due to the
NT have been subjected to superficial compaction for $8 \mathrm{yr}$, promoting a structural condition more resistant to compaction, not reaching the deepest layers. Bulk density presented moderate deformations with the induced compaction (Figure 3). Maximum deformation for this attribute was on layer $0-5 \mathrm{~cm}$ (Figure $3 \mathrm{a}$ ), with the effect being gradually reduced as the depth increased. For Tp, small deformations were observed even in the depths 0-5 and 5-10 cm (Figures $3 \mathrm{a}$ and $3 \mathrm{~b}$ ). Evaluating the soil physical quality in different cropping systems, Marchão et al. (2007) did not find substantial alterations in Tp and Bd, but the $0-5 \mathrm{~cm}$ depth presented the biggest modifications for these two attributes. According to Horn and Fleige (2009), Tp and Bd are properties of low indication of soil quality, being the influence of air capacity (macropores) and the available water capacity more important in stronger aggregated soils (e.g. clayey soils).

Resistance to penetration and Macro were the attributes that better represented the physical alterations occurred in no-till system (Figure 3 ). The axis of RP presented the biggest deformations up to the depth $0-15 \mathrm{~cm}$ (Figures 3a-3c). This corroborates Marchão et al. (2007), who observed that RP and Macro are the soil physical attributes

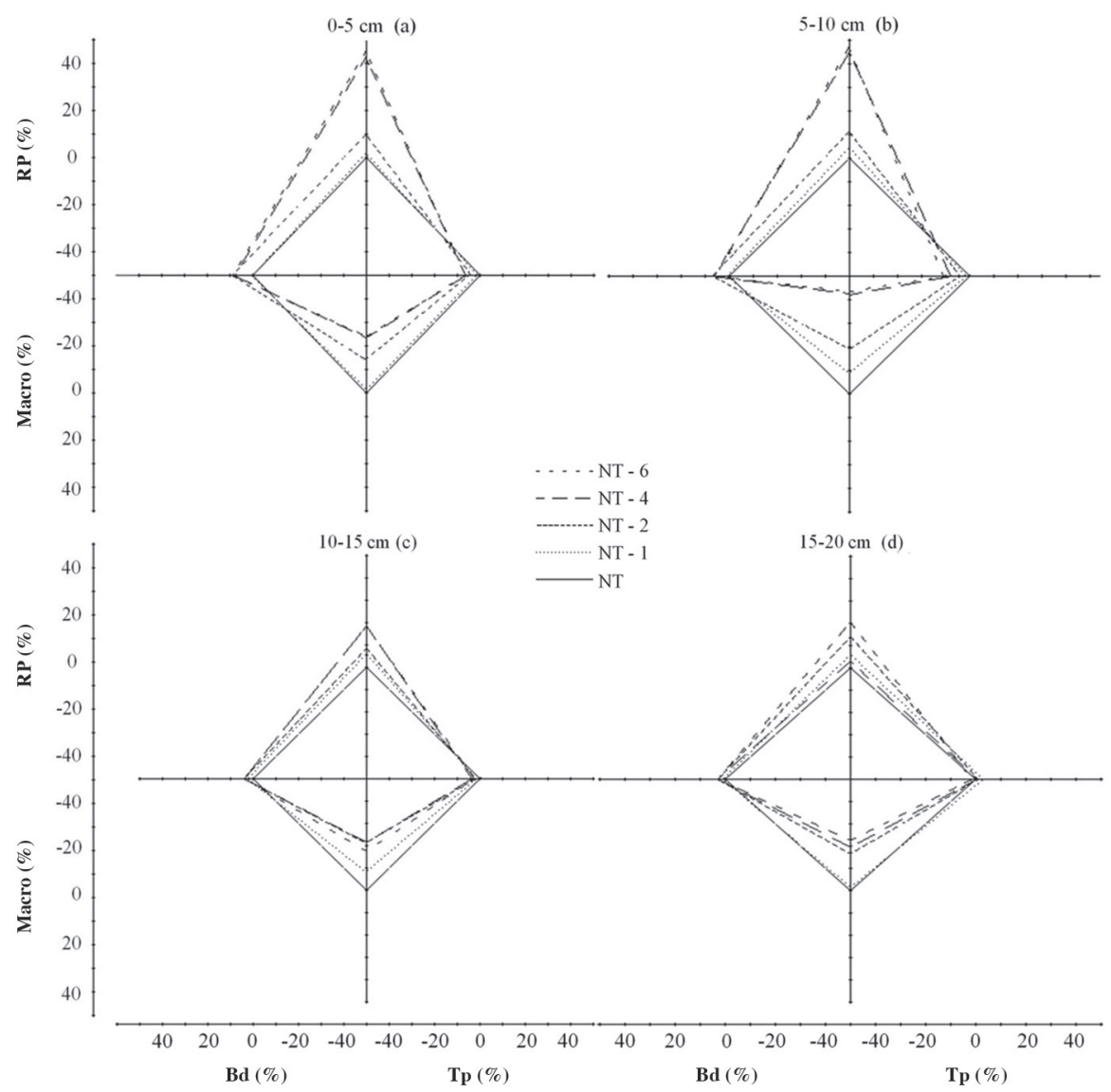

Figure 3. Graphical model comparing soil physical quality in a no-till system with additional compaction with the no-till system (NT), in depths 0-5 (a), 5-10 (b), 10-15 (c), and $15-20 \mathrm{~cm}(\mathrm{~d})$, considering the relative values of the attributes soil resistance to penetration (RP), macroporosity (Macro), bulk density (Bd), and total porosity (Tp). 
more sensible to changes caused by cropping systems. In agricultural soils, some of the most important indicators of physical quality include plant-available water capacity, air capacity, macroporosity, bulk density, and structural stability index (Reynolds et al., 2009).

Performing the principal component analysis (multivariate analysis) for treatments of 4- and 7-yrold conventional and no-tillage as a function of wheat (Triticum turgidum L. var. durum) yield and soil parameters in an Entic Haploxeroll of Central Chile, Martínez et al. (2008) observed that the first-two principal components explained $67.4 \%$ of the experimental variance, these being the mean-weight diameter of soil aggregates and soil porosity, which are related to soil structural stability and soil water and air mobility.

Other indicators of soil physical quality proposed by Reynolds et al. (2002) are the factors field capacity $(\mathrm{FC}) /$ porosity $(\mathrm{POR})=0.66$ and air capacity $(\mathrm{AC}) / \mathrm{POR}$ $=0.34$, for "ideal" storage capacity of soil water and soil air, given that they yield results consistent with existing guidelines, and they incorporate aspects of soil quality that are not included in other indicator parameters. A common feature among the above indicators is that they are all direct or indirect expressions of the volume and/or function of soil pore space (Reynolds et al., 2009). It is noteworthy that these indicators follow the same trend of the attributes found in the experiment that most influenced the soil physical quality, as Macro and RP, because they are directly related to the flow of air and water in the soil. Resistance to penetration and Macro are obvious functions of pore volume. Hence, pore characteristics are strongly linked to soil physical quality, and as a consequence, it should be possible to infer optimal pore volume/function characteristics from the various optimal (or optimized) soil physical quality indicators. However, the ability to identify optimal pore volume/function characteristics should in turn improve our understanding of the linkages among soil physical quality, environmental impact, crop productivity, and water and solute dynamics within the soil profile (Reynolds et al., 2009).

Increase on soil compaction, which was caused by tractor traffic, constrained the index of emergence velocity, stem diameter, and plant height (Table 3). Up to a single pass of tractor, the index of emergence velocity and the stem diameter were not affected. But, the accumulated pressure on soil from two to six tractor passages reduced these features of the crop, without differences among treatments (NT-2, NT-4, and NT6). The treatment NT-6 presented the shortest plant height but with no significant differences from NT-4. However, treatments NT, NT-1, and NT-2 presented higher height, with no differences among them. These results can be explained by the increase of the values of the RP induced by tractor traffic. To Freddi et al. (2008), a RP above $0.34 \mathrm{MPa}$ causes restrictions to the growth of maize plant.
Table 3. Index of emergence velocity (IEV), stem diameter (SD), plant height (PH), number of grain rows in a cob (NGRC), number of grains per row (NG), cob length (CL), mass of 100 grains (M100Gr) and maize yield (Yield) in distinct number of tractor traffic in a clayey Oxisol (Rhodic Hapludox).

\begin{tabular}{lrlllllll}
\hline Treatments $^{1}$ & IEV & SD & PH & NGRC & NG & CL & M100Gr & Yield \\
\hline & & $\mathrm{cm}$ & $\mathrm{m}$ & & & $\mathrm{cm}$ & $\mathrm{g}$ & $\mathrm{t} \mathrm{ha}^{-1}$ \\
NT & $10.3 \mathrm{a}$ & $2.1 \mathrm{a}$ & $2.26 \mathrm{a}$ & $14 \mathrm{a}$ & $39 \mathrm{a}$ & $17 \mathrm{a}$ & $33.0 \mathrm{a}$ & $7.70 \mathrm{a}$ \\
NT-1 & $9.4 \mathrm{a}$ & $2.1 \mathrm{a}$ & $2.22 \mathrm{ab}$ & $14 \mathrm{a}$ & $38 \mathrm{a}$ & $16 \mathrm{a}$ & $32.2 \mathrm{ab}$ & $7.63 \mathrm{a}$ \\
NT-2 & $6.6 \mathrm{~b}$ & $1.9 \mathrm{~b}$ & $2.21 \mathrm{ab}$ & $14 \mathrm{a}$ & $37 \mathrm{a}$ & $16 \mathrm{a}$ & $32.0 \mathrm{~b}$ & $7.62 \mathrm{a}$ \\
NT-4 & $6.5 \mathrm{~b}$ & $1.8 \mathrm{~b}$ & $2.19 \mathrm{bc}$ & $14 \mathrm{a}$ & $35 \mathrm{a}$ & $15 \mathrm{a}$ & $31.7 \mathrm{~b}$ & $7.11 \mathrm{ab}$ \\
NT-6 & $6.5 \mathrm{~b}$ & $1.8 \mathrm{~b}$ & $2.15 \mathrm{c}$ & $14 \mathrm{a}$ & $35 \mathrm{a}$ & $15 \mathrm{a}$ & $30.8 \mathrm{c}$ & $6.95 \mathrm{~b}$ \\
\hline CV, \% & 9.05 & 4.14 & 1.56 & 3.82 & 7.16 & 6.12 & 1.96 & 5.51 \\
\hline
\end{tabular}

${ }^{1}$ NT: no-tillage system; no-tillage with additional compaction by tractor traffic in one (NT-1), two (NT-2), four (NT-4), and six passes (NT-6).

Means followed by the same letter in the column did not differ according to the Duncan's test $(P \leq 0.05)$.

The variables number of grain rows per cob, number of grains per row, and cob length, were not altered by different treatments. But the mass of 100 grains and maize yield were negatively affected by soil compaction (Table 3). Treatment NT-6 comparing to the reference (NT) reduced mass of 100 grains and maize yield around $7 \%$ and $10 \%$, i.e., $2.2 \mathrm{~g}$ and $0.75 \mathrm{t} \mathrm{ha}^{-1}$, respectively. It was observed a tendency for higher maize yields in the treatments with less soil compaction (Table 3). Treatment NT-6 presented the smallest maize yield, not differing from NT-4. Treatments NT, NT-1, NT-2, and NT-4 did not significantly differ among each other and presented the highest maize yield. Freddi et al. (2008) studied the effects of compaction caused by a tractor weighing 11 $\mathrm{t}$, which caused $4 \%, 16 \%$ and $27 \%$ yield reduction on maize, respectively, for the tractor traffic once, twice, and four times compared to the absence of traffic.

Increase on soil compaction changed soil physical attributes and maize yield. To evaluate the relations of the attributes with maize yield, the correlation among these variables were determined (Figure 4). It has frequently been recognized that compaction reduces total porosity and increases bulk density while also reducing the proportion of larger pores that play an important role in water movement and solute transport, nutrient availability, aeration, and crop productivity (Arocena, 2000). Average values of attributes were used for the layer $0-10 \mathrm{~cm}$, because in this depth the biggest physical alterations were observed represented in the comparative graphical model (Figure 4). Only Macro, RP, GMD, and MWD presented significant correlations with maize yield (Figure 4). Therefore, only data of these correlations were presented as figures. Evaluation soil properties as indicators of soil physical for Brookston clay loam in Canada, Reynolds et al. (2009) identified as optimal ranges of soil quality, Bd of 0.9-1.2 $\mathrm{g} \mathrm{cm}^{-3}$, the predicted optimal ranges for plantavailable water capacity (PAWC), air capacity (AC), and macroporosity $\left(\mathrm{P}_{\mathrm{MAC}}\right)$ were $17-23 \mathrm{vol} . \%, 20-21$ vol.\%, and 7-9 vol.\%, respectively. Non-optimal soils with poor aeration capacity (low AC), poor structural quality (low $\mathrm{P}_{\mathrm{MAC}}$ ), and low structural stability (low structural stability index, SI) had greater proportions of small pores and 

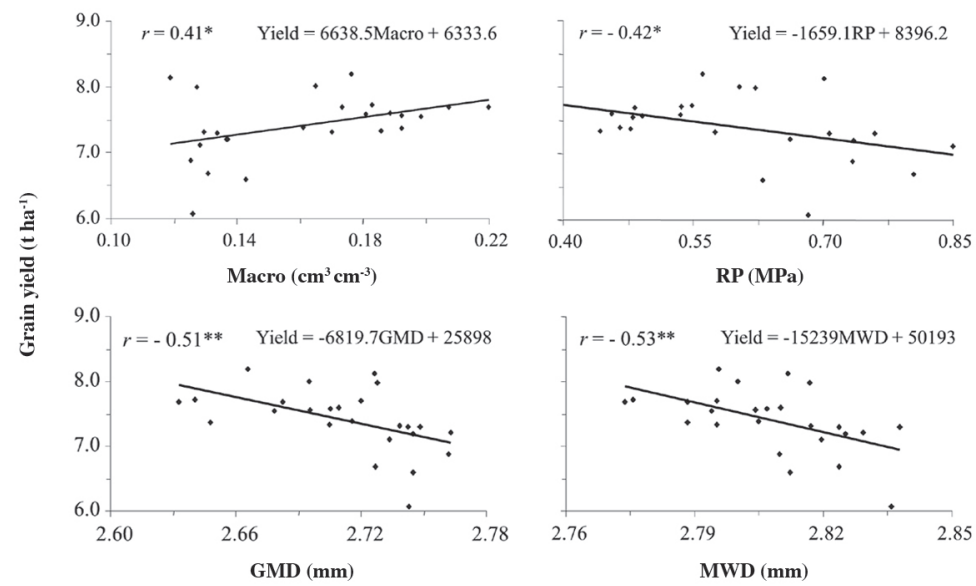

*, ** Significant at the 0.05 and 0.01 probability levels, respectively, according to test $t$.

Figure 4. Maize grain yield according to macroporosity (Macro), soil resistance to penetration (RP), geometric mean diameter (GMD), and mean weighted diameter (MWD). Layer from $0-10 \mathrm{~cm}(\mathrm{n}=25)$.

excessive water retention relative to soils with optimal physical quality. In non-optimal Brookston clay loam, Reynolds et al. (2009) found that the moving all physical quality indicators for the optimum range, there was an increase in maize yield $\left(2.1 \mathrm{t} \mathrm{ha}^{-1}\right)$, and improvements in the shape and location of the pore volume distribution and water release curve. Hence, the suite of indicators (PAWC, AC, $\mathrm{P}_{\mathrm{MAC}}, \mathrm{Bd}$, and SI) appears effective for quantifying the physical quality of rigid to moderately expansive agricultural soils.

The increase on RP, GMD, and MWD constrained linearly maize yield, while the increase of Macro benefited yield (Figure 4). Freddi et al. (2008) also found linear reduction of yield when RP was above $0.34 \mathrm{MPa}$. Hamza and Anderson (2005) mentioned that increases in $\mathrm{RP}$ and Bd can finally be reflected in lower crop yield. The increase in soil aggregate diameter can be due to the transference of load applied by machinery tires, making aggregates closer and increasing the volume of micropores, even if this does not make the benefits of closer aggregates to be present, causing yield decrease.

In this work it was possible to identify the importance of properties which integrate soil attributes in one value, as examples, RP, Macro, and aggregate stability which are very integrative about soil structure, being strong indices of soil physical quality. Indicators of soil quality can be defined loosely as those soil properties and processes that have greatest sensitivity to changes in soil functions (Andrews et al., 2004). Parr et al. (1992) suggested that increased infiltration, aeration, macropores, aggregate distribution and their stability and soil organic matter and decreased rate of $\mathrm{Bd}$ and soil resistance are some of the important indicators for improved soil quality. Resistance to penetration and Macro are influenced by the structural condition of the soil. They are altered by cultivation, loss of organic matter and compression by agricultural machinery, resulting in compact layer. Aggregate stability is affected by type and quantity of organic matter, types of clays, wetting and drying, chemicals elements in the soil, biological activity, cropping systems, and tillage practices.

\section{CONCLUSIONS}

Our findings showed that soil macroporosity increase and reduction of resistance to penetration benefit maize yield. The physical attributes evaluated, mainly soil resistance to penetration, macroporosity, and aggregate stability indices are sensitive enough to be adopted as indicators of soil physical quality, and also they are better related to the maize yields.

\section{ACKNOWLEDGEMENTS}

To Coordination for the Improvement of Higher Education Personnel (CAPES) for the scholarship provided that made this study possible to be developed.

\section{LITERATURE CITED}

Agostini, M. de los A., G.A. Studdert, S. San Martino, J.L. Costa, R.H. Balbuena, J.M. Ressia, et al. 2012. Crop residue grazing and tillage systems effects on soil physical properties and corn (Zea mays L.) performance. Journal of Soil Science and Plant Nutrition 12:271-282. doi:10.4067/S0718-95162012000200007.

Alaoui, A., J. Lipiec, and H.H. Gerke. 2011. A review of the changes in the soil pore system due to soil deformation: A hydrodynamic perspective. Soil and Tillage Research 115-116:115. doi:10.1016/j.still.2011.06.002.

Andrews, S.S., D.L. Karlen, and C.A. Cambardella. 2004. The soil management assessment framework: A quantitative evaluation using case studies. Soil Science Society of America Journal 68:1945-1962. 
Angers, D.A., B.D. Kay, and P.H. Groenevelt. 1987. Compaction characteristics of a soil cropped to corn and bromegrass. Soil Science Society of America Journal 51:779-783 doi:10.2136/sssa j1987.03615995005100030037x.

Arocena, J.M. 2000. Cations in solution from forest soils subjected to forest floor removal and compaction treatments. Forest Ecology and Management 133:71-80. doi:10.1016/S03781127(99)00299-6.

Blanco-Canqui, H., R. Lal, L.B. Owens, W.M Post, and R.C. Izaurralde. 2005. Mechanical properties and organic carbon of soil aggregates in the Northern Appalachians. Soil Science Society of America Journal 69:1472-1481. doi:10.2136/sssaj2004.0356.

Botta, G.F., D. Jorajuria, H. Rosatto, and C. Ferrero. 2005. Light tractor traffic frequency on soil compaction in the Rolling Pampa region of Argentina. Soil and Tillage Research 86:9-14. doi:10.1016/j.still.2005.01.014.

Bradford, J.M. 1986. Penetrability. p. 463-478. In Klute, A. (ed.) Methods of soil analysis. $2^{\text {nd }}$ ed. American Society of Agronomy, Madison, Wisconsin, USA.

CONAB. 2013. Acompanhamento de safra brasileira: Grãos, décimo primeiro levantamento. Companhia Nacional de Abastecimento (CONAB), Brasília, Brasil. Available at http://www.conab.gov. br/OlalaCMS/uploads/arquivos/13_08_09_10_43_44_boletim_ portuges_agosto_2013_port.pdf (accessed October 2013).

Costa, E.A., W.J. Goedert, e D.M.G. Souza. 2006. Qualidade de solo submetido a sistemas de cultivo com preparo convencional e plantio direto. Pesquisa Agropecuária Brasileira 41:1185-1191. doi:10.1590/S0100-204X2006000700016.

Embrapa. 1997. Manual de métodos de análise de solo. $2^{\text {a }}$ ed. Empresa Brasileira de Pesquisa Agropecuária (EMBRAPA), Centro Nacional de Pesquisa de Solos, Rio de Janeiro, Brasil.

Embrapa. 2013. Sistema brasileiro de classificação de solos. $3^{\text {a }}$ ed. Empresa Brasileira de Pesquisa Agropecuária (EMBRAPA), Centro Nacional de Pesquisa de Solos, Brasília, Brasil.

Ferrero, A., J. Lipiec, M. Turski, and A. Nosalewicz. 2007. Stability and sorptivity of soil aggregates in grassed and cultivated sloping vineyards. Polish Journal of Soil Science 40(1):1-8.

Freddi, O.S., J.F. Centurion, A.N. Beutler, R.G. Aratani, e A.N. Beutler. 2008. Compactação do solo e intervalo hídrico ótimo no crescimento da parte aérea e produtividade da cultura do milho. Irriga 13:272-287.

Hamza, M.A.M., and W.K. Anderson. 2005. Soil compaction in cropping systems. A review of the nature, causes and possible solutions. Soil and Tillage Research 82:121-145. doi:10.1016/j. still.2004.08.009.

Horn, R. 1990. Aggregate characterization as compared to soil bulk properties. Soil and Tillage Research 17:265-289. doi:10.1016/0167-1987(90)90041-B.

Horn, R. 2003. Stress strain effects in structured unsaturated soils on coupled mechanical and hydraulic processes. Geoderma 116:7788. doi:10.1016/S0016-7061(03)00095-8.

Horn, R., and H. Fleige. 2009. Risk assessment of subsoil compaction for arable soils in Northwest Germany at farm scale. Soil and Tillage Research 102:201-208.

Horn, R., and M. Kutilek. 2009. The intensity-capacity conceptHow far is it possible to predict intensity values with capacity parameters. Soil and Tillage Research 103:1-3.

Karlen, D.L., M.J. Mausbach, J.W. Doran, R.G. Cline, R.F. Harris, and G.E. Schuman. 1997. Soil quality: A concept, definition and framework for evaluation. Soil Science Society of America Journal 61:4-10. doi:10.2136/sssaj1997.03615995006100010001x.

Kemper, W.D., and R.C. Rosenau. 1986. Aggregate stability and size distribution. p. 425-441. In Klute, A. (ed.) Methods of soil analysis. $2^{\text {nd }}$ ed. American Society of Agronomy, Madison, Wisconsin, USA.

Köppen, W., und R. Geiger. 1928. Klimakarte der Erde. Wall-map $150 \mathrm{~cm} \times 200 \mathrm{~cm}$. Verlag Justus Perthes, Gotha, Germany.
Klute, A. 1986. Water retention: Laboratory methods. p. 635-662. In Klute, A. (ed.) Methods of soil analysis. $2^{\text {nd }}$ ed. American Society of Agronomy, Madison, Wisconsin, USA.

Leij, F.J., T.A. Ghezzehei, and D. Or. 2002. Modeling the dynamics of the soil pore-size distribution. Soil and Tillage Research 64:6178. doi:10.1016/S0167-1987(01)00257-4

Li, X., and L.M. Zhang. 2009. Characterization of dual-structure pore-size distribution of soil. Canadian Geotechnical Journal 46:129-141. doi:10.1139/T08-110.

Maguire, J.D. 1962. Speed of germination - aid in selection and evaluation for seedling emergence and vigor. Crop Science 2:176-177.

Marchão, R.L., L.C. Balbino, E.M. Silva, J.D.G. Santos Júnior, M.A.C. Sá, L. Vilela, et al. 2007. Qualidade física de um Latossolo Vermelho sob sistemas de integração lavoura-pecuária no Cerrado. Pesquisa Agropecuária Brasileira 42:873-882. doi:10.1590/S0100-204X2007000600015.

Martínez, E., J.P. Fuentes, P. Silva, S. Valle, and E. Acevedo. 2008. Soil physical properties and wheat root growth as affected by no-tillage and conventional tillage systems in a Mediterranean environment of Chile. Soil and Tillage Research 99:232-244. doi:10.1016/j.still.2008.02.001.

Pagliai, M., and R. Jones (eds.) 2002. Sustainable land managementenvironmental protection: A soil physical approach. Advances in GeoEcology 35. 588 p. Catena Verlag GMBH, Reiskirchen, Germany.

Parr, J.F., R.I. Papendick, S.B. Hornick, and R.E. Meyer. 1992. Soil quality: attributes and relationship to alternative and sustainable agriculture. American Journal of Alternative Agriculture 7:5-11. doi:10.1017/S0889189300004367.

Reynolds, W.D., B.T. Bowman, C.F. Drury, C.S. Tan, and X. Lu. 2002. Indicators of good soil physical quality: density and storage parameters. Geoderma 110:131-146. doi:10.1016/S00167061(02)00228-8.

Reynolds, W.D., C.F. Drury, C.S. Tan, C.A. Fox, and X.M. Yang. 2009. Use of indicators and pore volume-function characteristics to quantify soil physical quality. Geoderma 152:252-263. doi:10.1016/j.geoderma.2009.06.009.

Ribeiro Júnior, J.I. 2001. Análises estatísticas no SAEG. 301 p. Universidade Federal de Viçosa, Viçosa, Brasil.

Serafim, M.E., A.C.T. Vitorino, C.M.A. Souza, E.D. Prado, J.C. Venturin, e N.T. Yamamoto. 2008. Desenvolvimento de um penetrógrafo eletromecânico de bancada. Revista Ciências Técnicas Agropecuárias 17:61-65.

Servadio, P., A. Marsili, N. Vignozzi, S. Pellegrini, and M. Pagliai. 2005. Effects on some soil qualities in central Italy following the passage of four wheel drive tractor fitted with single and dual tires. Soil and Tillage Research 84:87-100. doi:10.1016/j. still.2004.09.018.

Silva, S.R., N.F. Barros, e L.M. Costa. 2006. Atributos físicos de dois Latossolos afetados pela compactação do solo. Revista Brasileira de Engenharia Agrícola e Ambiental 10:842-847. doi:10.1590/ S1415-43662006000400009.

Silveira Junior, S.D., A.P. Silva, G.C. Figueiredo, C.A. Tormena, e N.F.B. Giarol. 2012. Qualidade física de um Latossolo Vermelho sob plantio direto submetido à descompactação mecânica e biológica. Revista Brasileira de Ciência do Solo 36:1854-1867. doi:10.1590/S0100-06832012000600020.

Suzuki,L.E.A.,J.M.Reichert,D.J.Reinert, e C.L.R.Lima. 2007.Grau de compactação, propriedades físicas e rendimento de culturas em Latossolo e Argissolo. Pesquisa Agropecuária Brasileira 42:11591167. doi:10.1590/S0100-204X2007000800013.

USDA. 1999. Soil taxonomy. A basic system of soil classification for making and interpreting soil survey. $2^{\text {nd }}$ ed. Soil Survey Staff, Natural Resources Conservation Service (NRCS), United States Department of Agriculture (USDA), Washington D.C., USA. 